\title{
Kebijakan Formulasi Kualifikasi Yuridis terhadap Delik dalam Undang-Undang yang Lahir dalam Kurun Waktu 2014-2015
}

\author{
Ade Adhari \\ Fakultas Hukum, Universitas Tarumanagara \\ Email: adea@fh.untar.ac.id
}

\begin{abstract}
ABSTRAK
Dinamika produk perundang-undangan legislatif tahun 2014-2015 menunjukkan adanya perkembangan penggunaan hukum pidana sebagai sarana guna menanggulangi kejahatan. Hal ini terlihat dengan banyaknya undang-undang yang memuat ketentuan pidana. Namun sayangnya, kebijakan formulasi ketentuan pidana tersebut mengandung masalah yuridis. Salah satu masalah yuridis yang ada disebabkan karena tidak ditetapkannya kualifikasi yuridis berupa kejahatan atau pelanggaran dalam delik yang diatur dalam berbagai undang-undang tersebut. Tidak ditetapkannya kualifikasi yuridis menyebabkan aturan umum dalam Buku I KUHP tidak dapat diterapkan terhadap tindak pidana di luar KUHP. Untuk itu ke depan, pembentuk undang-undang harus menetapkan kualifikasi yuridis berupa kejahatan atau pelanggaran, guna menjembatani berlakunya aturan umum dalam KUHP terhadap delik-delik yang diatur dalam undang-undang di luar KUHP.
\end{abstract}

Kata Kunci: Kebijakan Hukum Pidana, Kebijakan Formulasi, Kualifikasi Yuridis

\section{PENDAHULUAN}

Praktik legislatif saat ini semakin menunjukkan terjadinya perubahan atau perkembangan fungsi hukum pidana dalam rangka memberikan perlindungan terhadap masyarakat dari yang bersifat ultimum remedium menjadi primum remedium. Pidana tidak lagi dilihat sebagai sarana terakhir dalam memberikan perlindungan, namun dalam kondisi tertentu dapat didudukkan sebagai sarana utama guna mencapai suatu kondisi di mana masyarakat mendapatkan perlindungan. Pilihan apakah pidana sebagai primum atau ultimum remedium sangat tergantung pada pilihan pembentuk undang-undang. Kondisi yang demikian sebetulnya telah ditangkap pula oleh Muladi dan Dwidja Priyatno:

"Dalam proses modernisasi dan pembangunan ekonomi yang semakin meningkat, muncul perkembangan baru dalam kaitannya dengan ruang lingkup dan fungsi hukum pidana dan sanksi pidana. Hukum pidana dalam hal ini digunakan sebagai sarana untuk meningkatkan rasa tanggung jawab negara dalam rangka mengelola kehidupan masyarakat modern yang kompleks. Sanksi pidana antara lain digunakan secara maksimal untuk mendukung norma administrastif dalam berbagai hal. Inilah yang dinamakan administrative penal law (verwaltungsstrafrecht) yang masuk dalam lingkup public welfare offences". "Selanjutnya keduanya menambahkan, dalam hal tindak pidana semacam ini, pemidanaan dilakukan atas dasar kepentingan masyarakat dan tidak atas dasar tingkat kesalahan subjektif” (Muladi \& Priyatno, 2012).

Di dalam memberikan perlindungan hukum bagi individu maupun masyarakat di Indonesia, pidana menjadi salah satu pilihan sarana yang dipilih oleh pembentuk undang-undang. Berbagai peraturan perundang-undangan yang memuat "ketentuan pidana" merupakan wujud konkret pilihan kebijakan yang dimaksud. Ketentuan pidana yang dimuat dalam berbagai produk legislatif salah satunya memuat aturan/ketentuan hukum pidana materiil/substantif. Menurut Barda Nawawi Arief (Arief, 2012), keseluruhan aturan/ketentuan pidana materiil/substantif merupakan suatu sistem, sehingga dapat disebut sebagai sistem hukum pidana materiil/substantif. Selanjutnya ditambahkan olehnya: 
"keseluruhan sistem hukum pidana substantif itu terdiri dari "aturan umum" (general rules) dan "aturan khusus" (special rules). Dilihat dari keseluruhan sistem penegakan hukum pidana substantif, UU Khusus di luar KUHP hanya merupakan "sub-sistem" karena pada umumnya hanya merumuskan tindak pidana/delik khusus. UU Khusus tidak mengatur keseluruhan bangunan/konstruksi konsepsional sistem hukum pidana yang bersifat umum (biasa disebut "ajaran-ajaran umum" atau "algemene leerstukken" '’algemeine lehren" (Arief, 2012).

Antara KUHP dan UU diluar KUHP dengan demikian terikat dalam satu kesatuan sistem pemidanaan. Keterikatan tersebut nampak darikarakteristik aturan umum sistem pemidanaan yang berlaku saat ini yang dikemukakan oleh Barda Nawawi Arief (Arief, 2012):

1. Ketentuan pidana dalam UU Khusus diluar KUHP merupakan sub-sistem dari keseluruhan sistem hukum pidana;

2. Sebagai sub-sistem, UU Khusus terikat pada ketentuan/aturan umum yang ada di dalam Bab I s/d VIII (Pasal 1-85) Buku I KUHP, sepanjang UU Khusus tidak membuat ketentuan lain yang menyimpang (Lihat Pasal 103 KUHP). Ini berarti, keterikatan UU khusus terhadap aturan umum itu tidak bersifat mutlak. UU Khusus bisa saja membuat ketentuan lain yang menyimpang;

3. Ketentuan/aturan umum dalam Bab IX Buku I KUHP (Pasal $86 \mathrm{~s} / \mathrm{d}$ 102) hanya berlaku untuk KUHP, tidak untuk UU khusus diluar KUHP (lihat Pasal 103 KUHP).

Keterikatan antara KUHP dengan UU Khusus diluar KUHP sayangnya sering tidak dipahami atau - diabaikan oleh pembentuk undang-undang. Ini yang menyebabkan banyaknya UU Khusus di luar KUHP yang mengandung masalah yuridis. Dengan meminjam makna masalah yuridis yang diintrodusir oleh Barda Nawawi Arief, bahwa yang dimaksud 'masalah yuridis' (dalam kebijakan formulasi) adalah suatu masalah perumusan 'dilihat dari kebijakan formulasi seharusnya' (menurut sistem hukum pidana/sistem pemidanaan yang sedang berlaku).

Kebijakan formulasi hukum pidana dalam berbagai peraturan perundang-undangan di Indonesia, saat ini banyak menimbulkan masalah yuridis. Tentunya pernyataan yang demikian, bukanlah sekedar-proposisi, opini-atau-asumsi belaka melainkan dapat dipertanggungjawabkan secara ilmiah atau didasarkan atas bukti-bukti (evidence-based). Salah satu masalah yuridis yang sering muncul dalam kebijakan formulasi UU khusus diluar KUHP adalah tidak ada penetapan kualifikasi yuridis berupa "kejahatan" atau "pelanggaran" terhadap delik-delik yang diatur dalam UU Khusus tersebut. Karena KUHP sebagai induk sistem hukum pidana materiil mengenal adanya pengkualifikasian tersebut, sehingga agar aturan umum dalam KUHP dapat diberlakukan terhadap delik-delik dalam UU Khusus di luar KUHP maka penetapan kualifikasi yuridis menjadi sebuah keharusan. Berdasarkan alasan-alasan tersebut di atas, maka terdapat dua permasalahan yang menjadi kajian yaitu bagaimana kebijakan penetapan kualifikasi yuridis dalam produk perundang-undangan tahun 2014-2015 dan bagaimana kebijakan penetapan kualifikasi yuridis dalam produk perundang-undangan di masa datang.

\section{METODE PENELITIAN}

Metode penelitian yang digunakan dalam penelitian ini adalah penelitian hukum doktrinal. Dalam operasionalnya menggunakan pendekatan undang-undang dan pendekatan konsep atau teoritik. Pendekatan tersebut digunakan untuk menganalisis hukum dalam ranah ius contitutum untuk kemudian digunakan untuk membangun ius constituemdum di bidang hukum pidana materiil. Data yang digunakan dalam penelitian ini adalah data sekunder yang meliputi bahan hukum primer berupa KUHP dan produk legislatif tahun 2014-2015 yang memuat ketentuan 
pidana, danbahan hukum sekuder seperti kajian-kajian yang bersifat ilmiah. Kemudian pada akhirnya bahan hukum yang diperoleh tersebut dianalisis dengan kaidah-kaidah keilmuan.

\section{HASIL DAN PEMBAHASAN}

\section{Kebijakan Penetapan Kualifikasi Yuridis dalam Produk Perundang-Undangan Tahun 2014-2015}

Benedict S. Alper menyatakan "crime is the oldest social problem" (Alpert, 1973). Senada dengan Benedict, Martina Henze menguraikan From the end of the eighteenth century, crime had been permanently on the agenda both among professionals and in the public (Henze, 2009). Dengan demikian, kejahatan tidak hanya tampak dalam fenomena sosial yang cakupannya lokal atau nasional (local/national phenomenon) melainkan juga internasional atau menurut istilah Seiichiro Ono sebagai 'a universal phenomenon'.

Digunakannya "pidana" untuk menanggulangi segala bentuk-bentuk kejahatan yang timbul di masyarakat adalah sebuah pilihan suatu masyarakat. Penggunaan sarana pidana dalam menanggulangi kejahatan dikenal dengan kebijakan hukum pidana atau politik hukum pidana (penal policy). Dipilihnya pidana sebagai sarana bukanlah merupakan sesuatu yang baru, melainkan telah lama dan banyak dilakukan oleh bangsa-bangsa beradab di dunia.

Kejahatan sebagai produk masyarakat selalu berkembang mengikuti perkembangan masyarakat. Semakin kompleks masyarakat, maka semakin kompleks pula persoalan kejahatan yang dihadapi suatu masyarakat. Di Indonesia sendiri, pembentuk undang-undang dalam hal ini Dewan Perwakilan Rakyat semakin giat menggunakan pidana sebagai sarana untuk menanggulangi kejahatan yang terjadi di segala bidang kehidupan. Hal ini bisa diidentifikasi dengan diterbitkannya berbagai undang-undang yang memuat ketentuan pidana.

Operasionalnya pidana sebagai cara dalam menanggulangi kejahatan pada pokoknya melalui tiga tahapan utama. M. Cherif Bassiouni, mengemukakan ketiga tahapan tersebut yakni tahap formulasi (proses legislatif), tahap aplikasi (proses peradilan/judicial) dan tahap eksekusi (tahap administrasi). Ketiga tahap tersebut dapat saja dipilah atau dibedakan masing-masing, namun sejatinya tidak dapat dipisah-lepaskan begitu saja. Karena masing-masing tersebut saling berhubungan satu sama lain. Konkretisasi pidana sebagai sarana penanggulangan tidak akan tercapai hanya dengan mengoptimalkan salah satu di antaranya. Seluruh tahapan tersebut harus selalu terhubung - dan terjalin satu sama lain. Pengoptimalan ketiga tahapan adalah suatu keharusan yang tidak dapat ditawar untuk menjadikan pidana sebagai alat yang berfungsi secara baik to combating crime.

Penetapan ketentuan pidana dalam berbagai peraturan perundang-undangan sebagaimana disinggung di atas, merupakan wujud nyata dari tahap formulasi. Tahap formulasi dapat dimaknai sebagai bagian dari rangkaian proses operasionalnya pidana dengan merumuskan dan menetapkan perbuatan-perbuatan mana yang dapat dipidana, jenis sanksi yang dapat dijatuhkan terhadap perbuatan yang dapat dipidana itu dan aturan atau pedoman pemidanaan terhadap perbuatan yang dinyatakan sebagai tindak pidana tersebut.

Tahapan formulasi sebagai tahapan awal hakikatnya harus didudukkan sebagai tahapan yang strategis dan penting. Tahap ini menentukan apakah pidana dapat dioperasionalkan pada tahap aplikasi (oleh aparat penegak hukum seperti hakim) dan tahap eksekusi (aparat pelaksanaan pidana). Kedudukan yang strategis dan penting ini menjadi logis karena aparat penegak hukum pada tahap aplikasi maupun eksekusi akan menerapkan pidana sesuai dengan ketentuan yang 
ditetapkan oleh pembentuk undang-undang pada tahap formulasi. Sehinga "kelengkapan" atau "kejelasan" ketentuan pidana yang ditetapkan akan mempengaruhi penerapannya di tahap-tahap selanjutnya (tahap aplikasi dan eksekusi). Dengan demikian pembentuk undang-undang semestinya menyusun sebuah sarana yang utuh sehingga ketentuan pidana yang di buat dapat menjadi panduan bagi aparat penegak hukum yang berwenang untuk mengaplikasi dan mengeksekusinya.

Sayangnya kedudukan tahap formulasi yang strategis dan penting tersebut nampaknya tidak dipahami oleh pembentuk undang-undang. Hal ini terlihat dengan masih banyaknya ketentuan pidana dalam berbagai peraturan perundang-undangan yang mengalami masalah yuridis, artinya belum disusun sesuai dengan sistem pemidanaan yang berlaku saat ini.

Menyusun ketentuan pidana tidak lagi dimaknai sebagai proses penyusunan yang sesuai dengan pendekatan keilmuan, yakni ilmu "kebijakan hukum pidana". Melainkan hanya dimaknai seolaholah sebagai "proses pencantuman pidana" untuk menakut-nakuti masyarakat agar menaati aturan yang dibuat atau ditetapkan. Pandangan yang berkembang dalam praktik penyusunan perundang-undangan yang demikian telah mereduksi hakikat dari tahapan formulasi dalam perspektif politik hukum pidana yang harusnya sebagai tahapan yang strategis dan penting sehingga mampu memberikan arah terang bagi aparat penegak hukum dalam mengaplikasikan dan mengeksekusi pidana. Praktik pembuatan kebijakan formulasi yang demikian harus disudahi, agar pidana sebagai sarana penanggulangan kejahatan dapat menjalankan fungsinya secara baik.

Selama periode 2014-2015, cukup banyak peraturan perundang-undangan yang telah ditetapkan oleh badan legislatif. Beberapa di antaranya mengandung ketentuan pidana. Berbagai ketentuan pidana yang ada dalam undang-undang tersebut masih banyak yang mengandung masalah yuridis. Permasalahan yuridis yang ada salah satunya adalah apabila pembentuk undang-undang tidak menetapkan kualifikasi delik berupa kejahatan atau pelanggaran terhadap delik-delik dalam berbagai undang-undang yang telah ditetapkan. Pengkualifikasian delik berupa kejahatan dan pelanggaran menurut sistem pemidanaan yang berlaku merupakan kualifikasi yuridis.

Setidaknya dalam kurun waktu 2014-2015 undang-undang yang memuat ketentuan pidana antara lain:

1. Undang-Undang No. 3 Tahun 2014 tentang Perindustrian/UU Peindustrian (Pasal 120-Pasal 121);

2. Undang-Undang No. 7 Tahun 2014 tentang Perdagangan/UU Perdagangan (Pasal 104-Pasal 116)

3. Undang-Undang No. 11 Tahun 2014 tentang Keinsinyuran/UU Keinsinyuran (Pasal 50Pasal 51);

4. Undang-Undang No. 20 Tahun 2014 tentang Standarisasi dan Penilaian Kesesuaian/UU Standarisasi dan Penilaian Kesesuaian (Pasal 62-Pasal 73);

5. Undang-Undang No. 21 Tahun 2014 tentang Panas Bumi/UU Panas Bumi (Pasal 67-Pasal $77)$;

6. Undang-Undang No. 28 Tahun 2014 tentang Hak Cipta/UU Hak Cipta (Pasal 112-Pasal 120);

7. Undang-Undang No. 29 Tahun 2014 tentang Pencarian dan Pertolongan/UU Pencarian dan Pertolongan (Pasal 82-Pasal 83);

8. Undang-Undang No. 33 Tahun 2014 tentang Jaminan Produk Halal/UU Jaminan Produk Halal (Pasal 56-57); 
9. Undang-Undang No. 36 Tahun 2014 tentang Tenaga Kesehatan/UU Tenaga Kesehatan (Pasal 83-Pasal 86);

10. Undang-Undang No. 37 Tahun 2014 tentang Konservasi Tanah dan Air/UU Konservasi Tanah dan Air (Pasal 59-Pasal 66);

11. Undang-Undang No. 39 Tahun 2014 tentang Perkebunan/UU Perkebunan (Pasal 103-Pasal 113);

12. Undang-Undang No. 40 Tahun 2014 tentang Perasuransian/UU Perasuransian (Pasal 73Pasal 82);

13. Undang-Undang No. 1 Tahun 2015 tentang Penetapan Peraturan Pemerintah Pengganti Undang-Undang No. 1 Tahun 2014 tentang Pemilihan Gubernur, Bupati, dan Walikota menjadi Undang-Undang/UU 1/2015jo. UU No. 8 Tahun 2015 tentang Perubahan atas Undang-Undang No. 1 Tahun 2015 tentang Penetapan Peraturan Pemerintah Pengganti Undang-Undang No. 1 Tahun 2014 tentang Pemilihan Gubernur, Bupati, dan Walikota menjadi Undang-Undang/UU No. 8/2015/UU 8/2015(Pasal 177-Pasal 198).

Paparan inventarisasi UU yang memuat ketentuan pidana di atas menunjukan pidana sebagai "sanksi primadona" bagi pembentuk undang-undang dalam mengatasi kejahatan di berbagai sendi kehidupan masyarakat. Dalam undang-undang tersebut diatur berbagai delik dan diketahui kebijakan formulasi kualifikasi yuridis (kejahatan atau pelanggaran) adalah sebagai berikut:

Tabel 1.Penetapan kualifikasi yuridis dalam produk legislatif 2014-2015

\begin{tabular}{clc}
\hline No. & \multicolumn{1}{c}{ Undang-Undang } & \multicolumn{2}{c}{ Ditetapkan Kualifikasi Yuridis } \\
\cline { 3 - 3 } & & \multicolumn{2}{c}{ Tidak } \\
\hline 1. & UU Perindustrian & $\sqrt{ }$ \\
\hline 2. & UU Perdagangan & $\sqrt{ }$ \\
\hline 3. & UU Keinsinyuran & $\sqrt{ }$ \\
\hline 4. & UU Standarisasi dan Penilaian Kesesuaian & $\sqrt{ }$ \\
\hline 5. & UU Panas Bumi & $\sqrt{ }$ \\
\hline 6. & UU Hak Cipta & $\sqrt{ }$ \\
\hline 7. & UU Pencarian dan Pertolongan & $\sqrt{ }$ \\
\hline 8. & UU Jaminan Produk Halal & $\sqrt{ }$ \\
\hline 9. & UU Tenaga Kesehatan & $\sqrt{ }$ \\
\hline 10. & UU Konservasi Tanah dan Air & $\sqrt{ }$ \\
\hline 11. & UU Perkebunan & $\sqrt{ }$ \\
\hline 12. & UU Perasuransian & UU 1/2015 jo. UU 8/2015 \\
\hline 13. & UU & \\
\hline
\end{tabular}

Berdasarkan penelusuran terhadap beberapa produk legislatif sebagaimana dimuat dalam tabel di atas didapat beberapa hal yakni:

a. Seluruh ketentuan pidana yang ditetapkan dalam berbagai UU tersebut tidak ada penetapan kualifikasi yuridis berupa kejahatan atau pelanggaran terhadap berbagai delik-delik yang diatur. Hal yang demikian dapat menimbulkan masalah yuridis. Pandangan yang demikian karena seperti telah disinggung di atas bahwa UU Khusus di luar KUHP terikat pada "sistem pemidanaan/sistem hukum pidana materiil" yang saat ini berinduk pada KUHP. Keterikatan tersebut adalah seperti dijelaskan oleh Barda Nawawi Arief di atas yaitu:

- Ketentuan pidana dalam UU Khusus di luar KUHP merupakan sub-sistem dari keseluruhan sistem hukum pidana;

- Sebagai sub-sistem, UU Khusus terikat pada ketentuan/aturan umum yang ada di dalam Bab I s/d VIII (Pasal 1-85) Buku I KUHP, sepanjang UU Khusus tidak membuat ketentuan lain yang menyimpang (Lihat Pasal 103 KUHP). Ini berarti, keterikatan UU 
khusus terhadap aturan umum itu tidak bersifat mutlak. UU Khusus bisa saja membuat ketentuan lain yang menyimpang;

- Ketentuan/aturan umum dalam Bab IX Buku I KUHP (Pasal 86 s/d 102) hanya berlaku untuk KUHP, tidak untuk UU khusus di luar KUHP (lihat Pasal 103 KUHP).

Ketentuan pidana dalam berbagai undang-undang khusus di luar KUHP dengan demikian terikat dalam sistem pemidanaan yang berlaku saat ini. Sehingga dalam penyusunannya harus memperhatikan sistem pemidanaan yang berlaku. Menurut sistem pemidanaan yang berlaku, UU Khusus di luar KUHP terikat pada aturan umum yang terdapat dalam Buku I KUHP Bab I-VIII (Pasal 1-85 KUHP), sepanjang tidak diatur secara khusus. Aturan umum yang terdapat dalam Buku I KUHP jelas membedakan antara "aturan umum untuk kejahatan" dan "aturan umum untuk pelanggaran". Adanya aturan umum untuk kejahatan dan pelanggaran tersebut menegaskan bahwa KUHP sebagai induk dalam sistem hukum pidana materiil mengenal adanya kualifikasi yuridis berupa kejahatan atau pelanggaran. Dalam hal ini, adanya pembedaan aturan umum untuk kejahatan dan pelanggaran merupakan wujud akibat yuridis dengan adanya pembedaan kualifikasi yuridis tersebut.

Penamaan delik sebagai kejahatan atau pelanggaran disebut sebagai kualifikasi yuridis selain karena pembentuk UU yang menetapkan, juga karena mengandung akibat-akibat yuridis terhadap masing-masing delik berkenaan dengan aturan umum pemidanaannya. Secara normatif, akibat-akibat yuridis yang dimaksud berupa adanya pembedaan antara aturan umum "percobaan dan pembantuan", "concursus", "daluwarsa penuntutan dan pelaksanaan pidana, "dalam hal delik aduan" dan sebagainya bagi tindak pidana yang dikualifikasi sebagai kejahatan dengan pelanggaran.

Pemberlakuan aturan umum dalam Buku I KUHP terhadap berbagai seluruh UU Khusus di luar KUHP termasuk 13 (tiga belas) undang-undang yang disebutkan di atas, dapat dilakukan apabila ketentuan pidananya telah menetapkan kualifikasi yuridis berupa kejahatan atau pelanggaran terhadap delik-delik yang diatur dalam ketentuan pidana tersebut. Sebagai bukti untuk menyatakan bahwa penetapan kualifikasi yuridis terhadap UU Khusus di luar KUHP agar dapat memberlakukan aturan umum KUHP adalah sebuah keharusan, berikut ini dapat dicermati dalam tabel berikut ini.

Tabel 2.Kualifikasi yuridis dan akibat yuridisnya

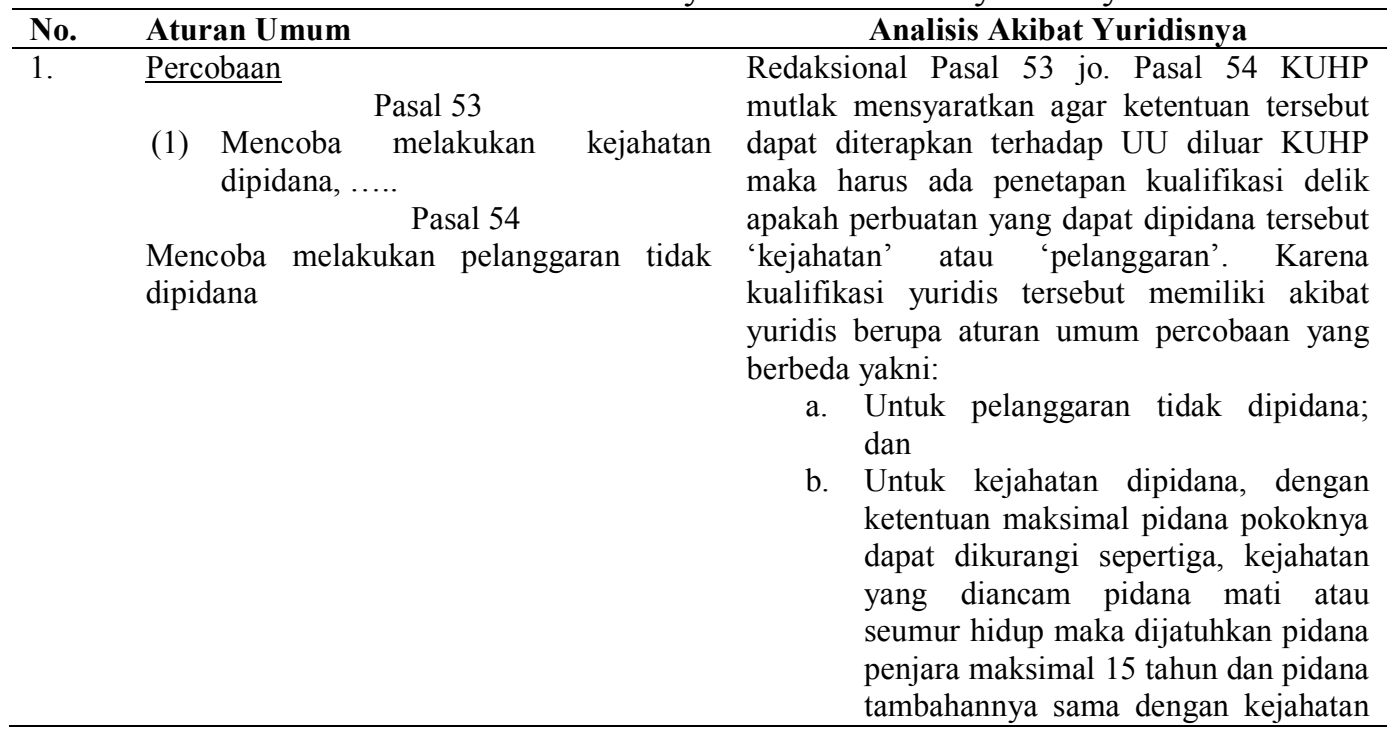


selesai.

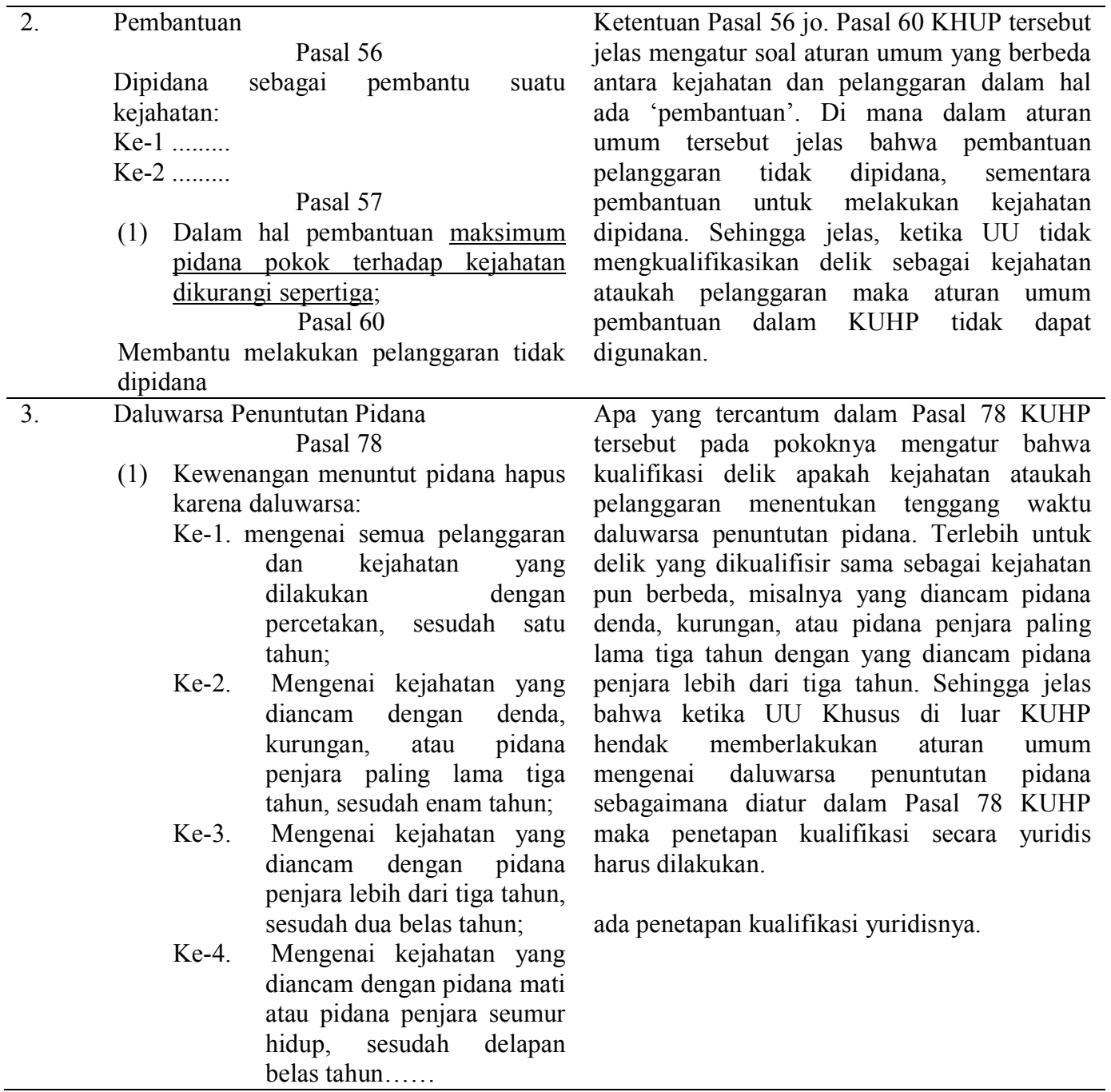

b. Salah satu undang-undang yang ditetapkan oleh pembentuk undang-undang pada tahun 2014-2015, tepatnya dalam UU Hak Cipta terdapat kualifikasi delik berupa delik aduan. Dalam Pasal 120 UU Hak Cipta dinyatakan tindak pidana sebagaimana dimaksud dalam Undang-Undang ini merupakan delik aduan. Berkenaan dengan hal tersebut logis apabila mencermati pandangan Barda Nawawi Arief berikut ini:

"delik aduan bukan merupakan kualifikasi yuridis, tetapi termasuk kualifikasi non-yuridis atau kualifikasi teoritik/ilmiah karena tidak disebutkan makna atau akibat yuridisnya. Delikdelik yang secara teoritik/keilmuan disebut sebagai delik aduan, antara lain delik perzinahan (Pasal 284 KUHP), delik-delik penghinaan (Pasal 310 KUHP), pencurian dalam keluarga (Pasal 367 KUHP), penggelapan dalam keluarga (Pasal 376 KUHP). Delik-delik itu disebut sebagai delik aduan karena dalam perumusan pasalnya ada ketentuan/klausul, bahwa tidak dilakukan penuntutan melainkan atas pengaduan pihak-pihak (subjek) yang disebut secara tegas dalam pasal yang bersangkutan. Jadi yang penting dirumuskan siapa (subjek) yang berhak mengadu, bukan nama/sebutan/kualifikasi deliknya. Kalau hanya disebutkan namanya saja (sebagai delik aduan), tetapi tidak dirumuskan secara tegas siapa yang berhak 
mengadu dan siapa penggantinya yang berhak mengadu, kapan tenggang waktu pengaduan, apa akibat hukumnya dan sebagainya, maka hal itu dapat menimbulkan masalah yuridis."

Perumusan "delik aduan" yang dinyatakan dalam Pasal 120 UU Hak Cipta sebetulnya tidak dilakukan oleh pembentuk undang-undang. Karena menurut sistem pemidanaan yang berlaku saat ini kualifikasi tersebut tidak memiliki akibat/konsekuensi yuridis dan merupakan kualifikasi yang diberikan oleh ilmu pengetahuan/teori/doktrin. Berkenaan dengan kualifikasi teoritik berupa delik aduan, yang terpenting adalah adanya ketentuan/klausul yang memungkinkan operasionalnya delik aduan tersebut (siapa (subjek) yang berhak mengadu, siapa penggantinya yang berhak mengadu, kapan tenggang waktu pengaduan, apa akibat hukumnya dan lain sebagainya) bukan sekedar penyebutannya sebagai "delik aduan oleh pembentuk undangundang". Kualifikasi delik yang harus ditetapkan oleh pembentuk undang-undang adalah kualifikasi yuridis seperti kejahatan atau pelanggaran.

Munculnya permasalahan yuridis berupa tidak ditetapkannya kualifikasi yuridis sebetulnya tidak mungkin terjadi apabila pembentuk undang-undang memperhatikan rambu-rambu yang terdapat dalam UU No. 12 Tahun 2011 tentang Pembentukan Peraturan Perundang-Undang (UU Pembentukan peraturan Perundang-Undangan) yakni perihal pedoman teknik penyusunan peraturan perundang-undangan yang dimuat dalam Lampiran II undang-undang tersebut.Ramburambu penyusunan perundang-undangan sebagaimana ditetapkan UU Pembentukan Peraturan Perundang-Undangan jelas tidak menjadi rujukan dalam setiap pembentukan undang-undang yang memuat ketentuan pidana. Jelas berkenaan dengan kualifikasi delik terdapat ketentuan yang menyatakan sehubungan adanya pembedaan antara tindak pidana kejahatan dan tindak pidana pelanggaran di dalam Kitab Undang-Undang Hukum Pidana, rumusan ketentuan pidana harus menyatakan secara tegas kualifikasi dari perbuatan yang diancam dengan pidana itu sebagai pelanggaran atau kejahatan.

\section{Kebijakan Penetapan Kualifikasi Yuridis dalam Produk Perundang-Undangan di Masa Datang}

Uraian pada bagian di atas memberikan pemahaman bahwa terdapat masalah yuridis dalam berbagai produk legislatif yang ditetapkan dalam kurun waktu 2014-2015. Masalah yuridis tersebut muncul akibat tidak ditetapkannya kualifikasi yuridis berupa kejahatan atau pelanggaran. Maka dalam menyusun kebijakan formulasi mendatang, hendaknya diperhatikan beberapa hal: pertama, penyusunan ketentuan pidana hendaknya mempertimbangkan berbagai pendekatan. Salah satunya adalah pendekatan keilmuan. Keilmuan yang dimaksud di sini adalah ilmu kebijakan hukum pidana. Menurut ilmunya, pidana tidak dapat operasional begitu saja. Melainkan melalui serangkaian tahapan yang saling memiliki keterhubungan satu sama lain sehingga tidak mungkin dipisah-lepaskan, tahapan tersebut meliputi tahap formulasi, tahap aplikasi dan tahap eksekusi. Tahap yang pertama disebut tersebut hendaknya didudukkan sebagai tahapan yang strategis dan penting dalam rangka menanggulangi kejahatan. Karena menentukan apakah pidana dapat dioperasionalkan oleh aparat penegak hukum di ranah aplikasi maupun eksekusi pidana.

Kedua, pembentuk undang-undang harus memahami, secara teoritik kualifikasi delik dibedakan menjadi kualifikasi yuridis dan kualifikasi non-yuridis/teoritik/ilmiah/keilmuan. J.A.W. Lensing menamakan pembedaan kualifikasi delik tersebut dengan "classified by statute" dan "classified by doctrine". Kualifikasi yuridis ditetapkan oleh pembentuk undang-undang, sedangkan kaulifikasi non-yuridis yang menetapkan adalah "ilmu pengetahuan/teori/doktrine". Sehingga 
dalam hal ini, yang perlu ditetapkan secara tegas oleh pembentuk undang-undang adalah berupa "kejahatan atau pelanggaran".

Ketiga, badan legislatif perlu memahami kedudukan ketentuan hukum pidana dalam sistem hukum pidana yang berlaku saat ini. Ketentuan pidana merupakan bagian dari sistem hukum pidana materiil yang berlaku saat ini. KUHP merupakan induk dalam sistem hukum pidana materil dan UU Khusus di luar KUHP terikat secara sistem. Oleh karena itu harus dicermati karakteristik dari sistem pemidanaan yang berlaku. Salah satu karakteristiknya adalah adanya pembedaan aturan umum mengenai kejahatan dan pelanggaran dalam Buku I KUHP. Sehingga untuk memberlakukannya, UU Khusus harus secara tegas menetapkan kualifikasi yuridisnya berupa kejahatan atau pelanggaran. Penetapan kualifikasi tersebut menjadi kewenangan dari pembentuk undang-undang. Pembentuk undang-undang yang mengetahui suatu delik layak dikualifikasi sebagai kejahatan atau pelanggaran. Lebih jauh, kebijakan penetapan kualifikasi delik berada pada tahap "kebijakan formulasi" dalam operasionalnya hukum pidana dan tahapan tersebut merupakan ranah dari pembentuk undang-undang.

Keempat, pembentuk undang-undang seyogyanya memahami hakikat dari hubungan antara norma hukum pidana dengan norma hukum lainnya seperti norma administratif. Norma hukum pidana dipandang sebagai norma pembantu (hulprecht) (Koentjoro, 2004). Norma hukum pidana yang terdapat dalam ketentuan pidana pada berbagai undang-undang dihadirkan dalam rangka untuk membantu agar norma hukum administratif (atau norma hukum lainnya) lebih ditaati. Sehingga karena fungsi yang sedemikian penting, sudah sepantasnya ketentuan pidana mendapat perhatian. Kelima, Keterikatan antara ketentuan pidana dalam UU Khusus diluar KUHP dengan KUHP memunculkan satu prinsip yang oleh Barda Nawawi Arief disebut "Prinsip Harmonisasi Kesatuan Sistem". Prinsip tersebut melahirkan salah satunya prinsip harmonisasi eksternal, yang menghendaki agar adanya keselarasan antara ketentuan hukum pidana dalam UU Khusus dengan aturan umum di dalam induk hukum pidana materiil yakni KUHP. Keselarasan tersebut dapat tercipta apabila diperhatikan karakteristik sistem hukum pidana yang berlaku. Karakteristik tersebut salah satu diantaranya adalah adanya pembedaan aturan umum antara kejahatan dengan aturan umum bagi pelanggaran. Untuk memberlakukan aturan umum terhadap tindak pidana dalam UU Khusus di luar KUHP, maka harus dilakukan penetapan kualifikasi yuridisnya berupa kejahatan atau pelanggaran oleh pembentuk undang-undang. Penetapan kualifikasi delik tersebut berfungsi untuk menjembatani berlakunya aturan umum dalam KUHP bagi tindak pidana di luar KUHP.

\section{SIMPULAN DAN SARAN}

\section{Simpulan}

a. Selama periode 2014-2015 cukup banyak produk legislatif yang memuat ketentuan pidana. Namun sayangnya ketentuan pidana yang tersedia mengandung masalah yuridis. Salah satu masalah yuridis yang dimaksud, tidak adanya formulasi kualifikasi yuridis berupa kejahatan atau pelanggaran terhadap delik-delik yang telah ditetapkan oleh pembentuk undang-undang. Ini berdampak secara yuridis berupa tidak dapat diterapkannya aturan umum dalam Buku I (Bab I-VIII) KUHP terhadap tindak pidana yang diatur dalam UU Khusus diluar KUHP.

b. Penyusunan kebijakan formulasi di masa yang akan datang seyogyanya pembentuk undangundang menetapkan kualifikasi yuridis berupa kejahatan atau pelanggaran terhadap berbagai delik yang ditetapkan dalam berbagai undang-undang khusus di luar KUHP. Penetapan kualifikasi delik tersebut bertujuan guna menjembatani berlakunya aturan umum KUHP terhadap tindak pidana di luar KUHP. 


\section{Saran}

a. Penggunaan pendekatan keilmuan dalam menyusun kebijakan formulasi ketentuan pidana, sehingga kebijakan yang diambil mendapat basis pertanggungjawaban ilmiah. Dengan penggunaan pendekatan ini, pembentuk undang-undang diharapkan memahami tahapan operasional hukum pidana, hakikat dan hubungan dari masing-masing tahapan kebijakan hukum pidana, pembedaan antara kualifikasi yuridis dengan kualifikasi non-yuridis, kedudukan ketentuan pidana dalam sistem hukum pidana materiil, fungsi hukum pidana dan prinsip harmonisasi baik internal maupun eksternal dalam sistem pemidanaan yang berlaku saat ini;

b. Penggunaan pendekatan normatif, dengan mencermati pedoman penyusunan ketentuan pidana yang terdapat dalam UU Pembentukan Peraturan Perundang-Undangan yang salah satunya, agar dalam setiap ketentuan pidana yang terdapat dalam UU Khusus di luar KUHP, pembentuk undang-undang menetapkan kualifikasi delik berupa kejahatan atau pelanggaran.

\section{REFERENSI}

Arief, B. N. (2012). Kebijakan formulasi ketentuan pidana dalam peraturan perundangundangan. Semarang: Pustaka Magister.

Alpert, B. S. (1973, October). Changing Concepts of Crime and Criminal Policy, Section 1: Expert Papers, Resource Material Series No. 6, UNAFEI, Tokyo, Japan.

Department of Economic and Social Affairs, Fourt United Nations Congress on The Prevention of Crime and the Treatment of Offenders, Kyoto, Japan, 17-26 August 1970.

Henze, M. (2009). Crime on the Agenda: Transnastional Organozations 1870-1955, Historik Tidsskrift.

Kitab Undang-Undang Hukum Pidana.

Koentjoro, D. H. (2004). Hukum Administrasi Negara. Bogor: Ghalia Indonesia.

Muladi \& Priyatno, D. (2012). Pertanggungjawaban Pidana Korporasi. Jakarta: Kencana.

Sudikno (2014). Penemuan hukum: Sebuah pengantar. Yogyakarta: Cahaya Atma Pustaka.

Undang-Undang No. 1 Tahun 2014 tentang Pemilihan Gubernur, Bupati, dan Walikota menjadi Undang-Undang.

Undang-Undang No. 1 Tahun 2015 tentang Penetapan Peraturan Pemerintah Pengganti UU No. 8 Tahun 2015 tentang Perubahan atas Undang-Undang No. 1 Tahun 2015 tentang Penetapan Peraturan Pemerintah Pengganti Undang-Undang No. 1 Tahun 2014 tentang Pemilihan Gubernur, Bupati, dan Walikota menjadi Undang-Undang.

Undang-Undang No. 3 Tahun 2014 tentang Perindustrian.

Undang-Undang No. 7 Tahun 2014 tentang Perdagangan.

Undang-Undang No. 11 Tahun 2014 tentang Keinsinyuran.

Undang-Undang No. 12 Tahun 2011 tentang Pembentukan Peraturan Perundang-Undang Undang-Undang No. 20 Tahun 2014 tentang Standarisasi dan Penilaian Kesesuaian.

Undang-Undang No. 21 Tahun 2014 tentang Panas Bumi.

Undang-Undang No. 28 Tahun 2014 tentang Hak Cipta.

Undang-Undang No. 29 Tahun 2014 tentang Pencarian dan Pertolongan.

Undang-Undang No. 33 Tahun 2014 tentang Jaminan Produk Halal.

Undang-Undang No. 36 Tahun 2014 tentang Tenaga Kesehatan.

Undang-Undang No. 37 Tahun 2014 tentang Konservasi Tanah dan Air.

Undang-Undang No. 39 Tahun 2014 tentang Perkebunan.

Undang-Undang No. 40 Tahun 2014 tentang Perasuransian. 